\title{
Den problematiska terroristlagstiftningen
}

\author{
Af Janne Flyghed ${ }^{l}$
}

I NTfK nr. 3/2012 skrev Per Ole Träskman en intresseväckande artikel om organiserad brottslighet, ekonomisk brottslighet och terrorism. Dock ställer jag mig tveksam till hans påstående att det idag knappast finns »någon anledning att inte acceptera den begreppsbestämning som finns i EU:s rambeslut av den 13 juni 2002 om bekämpande av terrorism«.

Rambeslutets definition av terrorism är nämligen problematisk. Det har framförts kritik att definitionens oklarhet riskerar att leda till att alla som begår olagligheter i samhällsomstörtande syfte kan komma att straffas som terrorister. Definitionen återfinns i den svenska lagen om straff mot terrorbrott (2003:148); en lag som implementerats som en konsekvens av EU:s rambeslut. Rambeslutet i sin tur var en konsekvens av USA:s initierade krig mot terrorismen där EU utsattes för visst tryck att ansluta sig (Se t.ex. dåvarande president Bushs brev till likaledes dåvarande EU-presidenten Prodi för USA:s önskelista om europeiskt support, 011016). Det kan vara värt att beakta att det internationella samfundet under lång tid dessförinnan försökte enas kring en definition om terrorism, men ständigt misslyckades, till stor del beroende på problemen med att komma överens om vad som ska betraktas som en legitim politiskt handling respektive en renodlat kriminell sådan. Efter 11 september 2001 tog det dock inte lång tid förrän man hade lyckats komma fram till en sådan.

I korthet innebär Lagen om brott mot terroristbrott betydande straffskärpningar för en mängd redan straffbelagda handlingar om de är att betrakta som terroristbrott. Rambeslutets definition av vad som är terrorism blir här helt avgörande. Det huvudsakliga problemet är de vagheter som finns i beskrivningen av de tre kriterier som ska gälla för att en handling ska betraktas som terrorbrott. Vad är t.ex. att »injaga allvarlig fruktan hos en befolkningsgrupp«? Eller att »Tvinga offentliga organ eller en mellanstatlig organisation att vidta eller att avstå från att vidta en åtgärd «? Även det tredje kriteriet, »allvarligt destabilisera eller förstöra grundläggande politiska, konstitutionella, ekonomiska eller sociala strukturer i en stat eller i en mellanstatlig organisation«, är problematiskt. Dessa formuleringar utesluter inte att t.ex. demonstrerande lantarbetare som obstruerar ett WTO-möte genom att med sina traktorer blockera alla infarter till Paris eller att politiska demonstrationer som utvecklar sig till stenkastande upplopp, kan komma att omfat- 
tas av definitionen. Efter EU-toppmötet i Göteborg sommaren 2001 benämndes redan då i EU-sammanhang händelserna som »terrorliknande«. Gränsdragningen mellan vad som är ett terroristbrott och mindre svårartade former av kriminalitet blir med andra ord otydlig.

Möjligheten till straffskärpning vid terroristbrott innebär också att polisens kan använda straffprocessuella tvångsmedel i större utsträckning än tidigare. Oavsett vilken straffskala brottet annars har, ska det vid terroristmotiv bestraffas med fängelse lägst fyra år och högst tio år eller på livstid. Är brottet mindre grovt kan straffet bli lägst två år och högst sex år. Även försök, förberedelser eller stämpling samt underlåtenhet att avslöja terroristbrott omfattas av lagen. Det ger möjlighet till att t.ex. hemlig teleavlyssning kan användas för samtliga brott som räknas upp i lagen om det enskilda fallet uppfyller kriterierna för terroristbrott. Denna vidgade möjlighet har uppenbarligen utnyttjats av polis och åklagare. Dock har de svenska domstolarna bedömt att endast två av närmare ett tjugotal åtal räckt till fällande dom. Vidare har enligt chefen för åklagarkammaren för säkerhetsmål, Tomas Lindstrand, ett betydligt större antal förundersökningar inletts med stöd av rambeslutets definition av terroristbrott men vilka inte kommit till allmänhetens kännedom. Hur många det rör sig om som hålls enligt Lindstrand hemligt. Således förundersökningar som med största sannolikhet inte kunnat påbörjas utan implementeringen av EU:s rambeslut.

Ett särskilt yttrande av ministerrådet i samband med rambeslutet stöder indirekt uppfattningen att definitionen av terroristbrott inte är helt oproblematisk. Där sades »att beslutet inte kan tolkas så att man hävdar att beteendet hos dem som har arbetat för att bevara och återupprätta demokratiska samhällen som respekterar rättsstaten och den civilisation på vilken dessa samhällen bygger, vilket i synnerhet var fallet i några medlemsstater under andra världskriget, nu kan betraktas som terroristhandlingar. Det får inte heller tolkas så att man på terroristgrunder anklagar personer som utövar sin grundläggande rätt att lägga fram sina åsikter, även om de begår brott när det utövar en sådan rätt.« (SOU 2003:32,197). Om det nu verkligen skulle var en entydig definition av vad som ska betraktas som en terroristhandling så kan man fråga sig varför ett sådant tillägg är nödvändigt.

Följande sentens är fortfarande ett gott memento att ha $i$ åtanke vid terroristlagstiftning. »Terrorismen kan inte lagstiftas bort. Däremot kan det som kallas rättsstaten mycket lätt förintas genom ny lagstiftning « (Träskman 1986:461). EU:s rambeslut och den svenska Lagen om straff mot terrorbrott innebär just en sådan risk.

\section{Note}

1. Kriminologiska institutionen, Stockholms universitet 